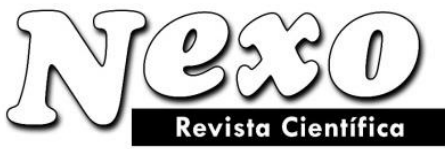

ISSN-E 1995-9516

Universidad Nacional de Ingeniería COPYRIGHT @ (UNI). TODOS LOS DERECHOS RESERVADOS

http://revistas.uni.edu.ni/index.php/Nexo

https://doi.org/10.5377/nexo.v34i06.13133

\title{
Thermal studies of vacuum panels of cellular structure of a passenger car
}

\section{Estudios térmicos de paneles de vacío de estructura celular de un coche de pasajeros}

\author{
Anatoly N. Balalaev*, Maria A. Parenyuk, Dmitry M. Timkin \\ Samara State Transport University. Samara, Russian Federation. \\ *Corresponding author E-mail: wagon.samgaps@mail.ru
}

(recibido/received: 12-octubre-2021; aceptado/accepted: 01-diciembre-2021)

\begin{abstract}
Aluminum alloys and composite materials are used in the body structures of modern passenger railway cars, which required the use of new manufacturing technologies: extrusion, pultrusion, etc. The use of new materials and new production technologies is changing the design requirements of passenger rail cars. The use of computer-aided design systems, in particular, SolidWorks Simulation, allows you to optimize the profile of cellular panels used in the construction of the body of a passenger railway car and obtained by extrusion or 3-D printing. Purpose of this work is to optimize the design stage of the enclosing structures of the body of a passenger railway car made of cellular profile panels, which can significantly reduce the heat transfer coefficient of the body walls and their mass, as well as provide the necessary strength conditions. Optimal profile of the vacuum panel, consisting of two rows of hexagonal cells, provides, according to calculations, the value of the specific thermal resistance $\mathrm{R}=2.922(\mathrm{~m} 2 \mathrm{~K}) / \mathrm{W}$, which is $16.5 \%$ more than that of the existing body structure of a passenger rail car.
\end{abstract}

Keywords: Passenger railway car; Thermal resistance; Vacuum panel.

\section{RESUMEN}

Las aleaciones de aluminio y los materiales compuestos se utilizan en las estructuras de la carrocería de los vagones de pasajeros modernos, que requerían el uso de nuevas tecnologías de fabricación: extrusión, pultrusión, etc. El uso de nuevos materiales y nuevas tecnologías de producción está cambiando los requisitos de diseño de los vagones de pasajeros. . El uso de sistemas de diseño asistido por computadora, en particular SolidWorks Simulation, permite optimizar el perfil de los paneles celulares utilizados en la construcción de la carrocería de un vagón de pasajeros y obtenidos por extrusión o impresión 3-D. El propósito de este trabajo es optimizar la etapa de diseño de las estructuras de cerramiento de la carrocería de un vagón de pasajeros hechas de paneles de perfil celular, que pueden reducir significativamente el coeficiente de transferencia de calor de las paredes de la carrocería y su masa, así como proporcionar la necesaria condiciones de fuerza. El perfil óptimo del panel de vacío, que consta de dos filas de celdas hexagonales, proporciona, según los cálculos, el valor de la resistencia térmica específica $\mathrm{R}=2.922(\mathrm{~m} 2 \mathrm{~K})$ / W, que es un 16,5\% más que el de la estructura de la carrocería existente de un vagón de pasajeros.

Palabras claves: Vagón de tren de pasajeros; Resistencia térmica; Panel de vacío. 


\section{INTRODUCTION}

Modern passenger railway cars operated in the northern regions of Russia need a body guard that has the maximum possible thermal resistance, since its value significantly affects the amount of energy spent on heating (Shavyrin et al., 2017). With an increase in the number of electric energy consumers in a passenger car, there is a need to reduce energy consumption for heating by designing new enclosing structures of the body that have a higher thermal resistance (Balalaev et al., 2018a).

The world has accumulated quite a lot of experience in the use of various thermal insulation materials. The most effective thermal insulation is vacuum thermal insulation (European Cooperation for Space Standardization, 2008), which is mainly used in space technology (NASA, 1999). However, vacuum thermal insulation is difficult to manufacture and high cost. Ensuring the strength and thermal insulation properties of the body of a modern passenger railway car is usually achieved by using sandwich panels that include a layer of thermal insulation (Önder and Robinson, 2020). The bodies of high-speed railway passenger cars are made of honeycomb panels (Yao et al., 2018).

The authors proposed to seal the panels of the honeycomb structure, to vacuum their internal cavities, and to use such panels as thermal insulation of the body of a railway passenger car (Balalaev et al., 2015a, 2015b, 2018a). In this paper, the heat engineering properties of vacuum thermal insulation obtained from a panel of cellular structure are evaluated.

\section{METHODOLOGY}

The use of cellular profile panels in the body structure of a passenger railway car can be carried out in the following directions: the first direction - the body of a passenger railway car consists of hollow pressed aluminum alloy panels with additional internal or external thermal insulation (Andronchev and Balalaev, 2013); the second direction - the body of a passenger railway car consists of polyamide cellular profile panels, the inner cavity of which is evacuated (Balalaev et al., 2018a); the third direction - the body of a passenger railway car consists of a steel frame, an outer skin made of steel sheet and an inner skin made of plastic, between which there are layers of heat and sound insulation, including vacuum insulation in the form of polyamide panels of cellular profile (Balalaev et al., 2018b). Figure 1 shows a fragment of the body of a passenger railway car, corresponding to the most promising, according to the authors, the third direction.

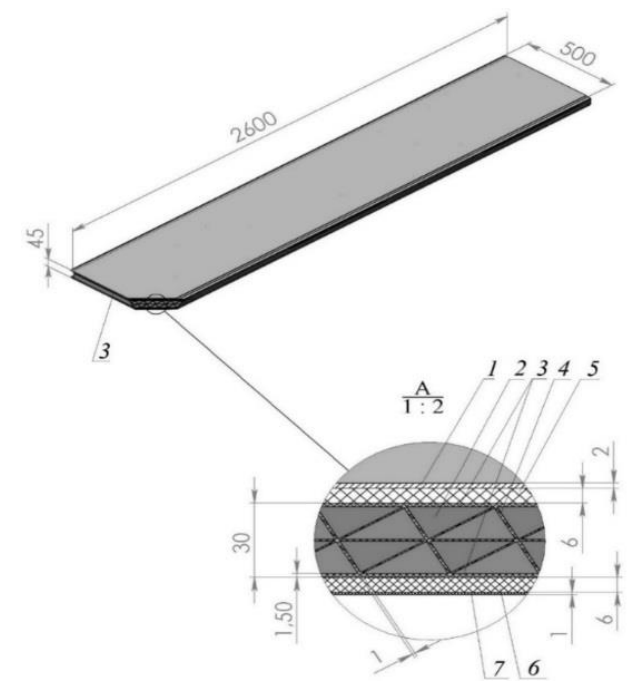

Figure 1. Model of a multi-layer fence with vacuum insulation in the form of a polyamide honeycomb panel: 1-external steel wall, 2-vacuum thermal insulation element, 3- external polyamide shell, 4-internal stiffeners, 5-foam thermal insulation material, 6-sound insulation material, 7-internal decorative wall. 
The purpose of this work is to evaluate the effectiveness of various models of the passenger railway car body and their cellular panels in comparison with the basic model of the passenger railway car body element. For the basic model, the design of the body wall of a passenger railway car is adopted, similar to the one shown in Figure 1, but without the cellular structure panel.

In the SolidWorks Simulation software package, to calculate the static strength of the car body model, a load was set, the value of which was selected from the conditions for ensuring the set value of the minimum safety factor of the base model $K_{F O S}=2$ with the size of the finite element grid $\Delta \min =0.001 \mathrm{~m}$. To simulate the effect of atmospheric pressure on the hollow cell of the model in which a vacuum is created, the studied panels of the cellular profile were loaded with a pressure of $100000 \mathrm{~Pa}$. In addition, for each variant of the cellular profile panel in SolidWorks Simulation, a thermal study was conducted to find the specific thermal resistance. In thermal studies, convective and radiation heat exchange inside the cells was neglected.

When optimizing the geometry of the panel cells, not only the height and thickness of the walls and edges were changed, but also the number of rows of cells and the shape of the cells (triangular, tetragonal, hexagonal). Variants of the cell structure profiles of the proposed models with different cell shapes and different number of rows are shown in Figure 2.

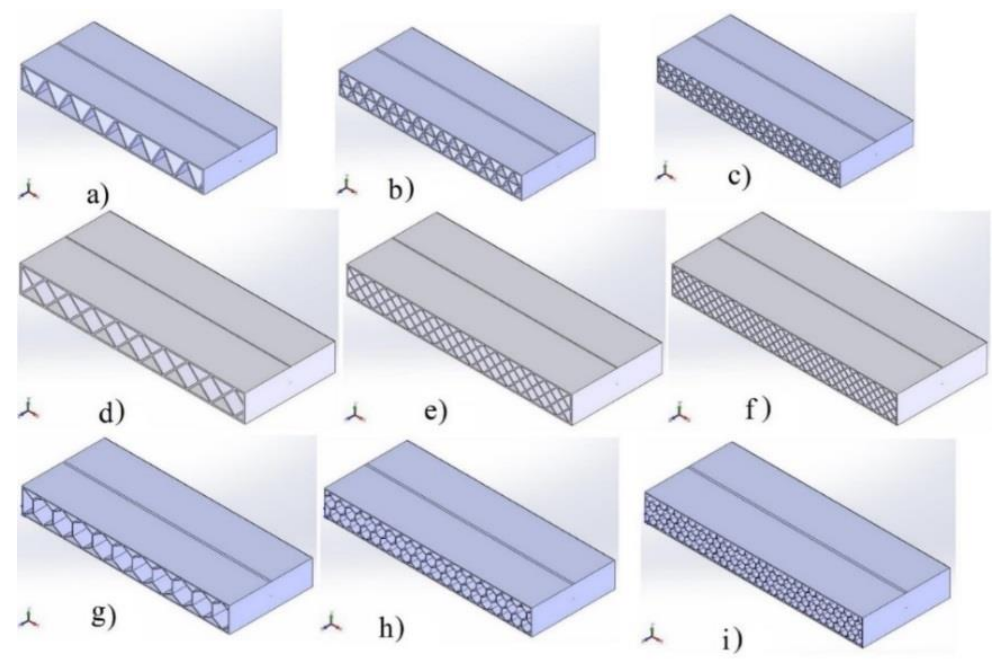

Figure 2. Variants of cell structure profiles of the proposed models: $a$ - triangular cells in one row; $b$ - triangular cells in two rows; c-triangular cells in three rows; d-tetragonal cells in one row; e-tetragonal cells in two rows; F-tetragonal cells in three rows; G-c-hexagonal cells in one row; $\mathrm{h}$ - hexagonal cells in two rows; $\mathrm{i}$ - hexagonal cells in three rows.

As can be seen from Figure 2, the proposed profiles differ in symmetry, but in the models from "a" to "e", it was possible to arbitrarily change the angles between the stiffeners.

The following optimization criteria were used to select the optimal profile of the proposed car body guard models:

$$
\operatorname{Keff}_{i}=\lambda_{1} \cdot\left(1-\frac{M_{i}}{M_{\text {base }}}\right)+\lambda_{2} \cdot\left(1-\frac{R_{\text {base }}}{R_{i}}\right)
$$

where $i$ - the serial number of the profile variant of the cellular structure; $\lambda_{1}, \lambda_{2}$-weight coefficients; 
$M_{i}, M_{\text {base }}$-weight of the new and basic body structure, $\mathrm{kg} ; R_{i}, R_{\text {base }}$ - specific thermal resistance of the new and basic body structure, $\left(\mathrm{m}^{2} * \mathrm{~K}\right) / \mathrm{W}$.

From the maximum condition of criterion (1), the optimal profile of various cellular panels was found. For the optimal profile of the honeycomb panel, the properties of a hypothetical orthotropic material from which a solid plate of equal thickness and equivalent strength can be made were established. Further, the threedimensional model of the body of a passenger railway car was made up of solid plates of such an orthotropic material and designed for strength in accordance with the current regulatory document for a passenger railway car. As a result of the calculations, the required thickness of solid plates was determined for each part of the body of a passenger railway car (roof, side walls, end walls, floor). For solid plates of a given thickness, the geometry of the panels of the optimal cellular profile was selected, providing equal strength. From the obtained panels of the optimal cellular profile, a model of the body of a new passenger railway car was compiled, its mass and thermal characteristics were specified. Thus, the method of evaluating the effectiveness of the use of cellular panels in the body structure of a passenger railway car allows you to design the body of a passenger railway car from hollow panels of cellular profile with optimal overall dimensions.

\section{LUTERATURE REVIEW}

The complexity of the study of the thermal properties of vacuum panels of cellular structure lies in the significant heterogeneity of the internal structure, which is also characteristic of heat-insulating sandwich panels. These difficulties are described in the works on the study of the thermal insulation properties of precast concrete sandwich panels (O'Hegarty et al., 2020). Numerical methods for studying such panels are carried out using the finite element method (Zhuming, 2019). A numerical study of the thermal properties of the vacuum panels of the cellular structure that make up the flat walls of the body of a passenger railway car was performed using the finite element method in (Balalaev et al., 2018a). The results of the study of such cylindrical panels are presented in (Balalaev et al., 2020b).

In (Balalaev et al., 2020a), a method for experimental determination of the thermal resistance of vacuum panels of a cellular structure is proposed. According to this method, the heat flow is created by the heat source and is divided into two parts. The first part of the heat flow first passes through the first reference object with high thermal conductivity, and then through the analyzed object. The temperature dependence of the first reference object on time is measured. Second part of the heat flow passes through a second reference object with high thermal conductivity, and then through a heat-resistant material. Temperature dependence of the second reference object on time is measured. It is necessary to determine the time intervals during which the temperature of the first and second reference objects increases by a given amount at seven different levels of the initial temperatures of the first and second reference objects. Substituting the values of the differences in the time intervals during which the temperature of the first and second reference objects increases by a given amount, a system of seven equations with respect to seven unknown quantities is solved in the heat balance equations using a computing device, one of which is the desired value - the specific thermal resistance of the object under study.

In (Andronchev and Balalaev, 2013), it was noted that an important step towards creating a new generation of rolling stock is the design of railway car bodies, the walls of which are made of aluminum honeycomb profiles with vacuumed internal parts. Such profiles can perform two functions: load-bearing and thermal insulation. In (Balalaev et al., 2018b), the authors proposed to separate the functions of strength support and thermal protection of the body of a passenger railway car, in the walls of which vacuum thermal insulation panels are used. This made it possible to significantly reduce the value of the average heat flow through the outer wall of the housing. 
The paper (Balalaev et al., 2018a) presents the results of calculating the heat transfer through an extruded panel made of polyamide "PA 6" with a profile in the form of triangular honeycombs arranged in several rows. The analysis of the sources showed that one of the promising directions for reducing the heat transfer coefficient of the body walls is the use of vacuum panels of cellular profile in the body housing. In addition, when protecting the body with such panels, the conditions of strength, sound insulation and fire safety must be introduced. In this regard, an urgent task is to find new design solutions in the field of housing enclosing structures made of vacuum panels of cellular profile, which can significantly reduce their heat transfer coefficient, reduce the weight of the product and provide the necessary conditions for strength and sound insulation.

\section{RESULTS}

This paper presents the results of optimizing the profile of cellular panels of the railing of the passenger rail car body. In the strength calculations for this model, the variants of profiles of cellular structures with different cell shapes and different number of rows, as well as the dimensions of wall and edge thicknesses, were changed. As an optimization criterion, the expression (1) was used, in which the weight coefficients for the second model had the following values: $\lambda_{1}=0,5 ; \lambda_{2}=0,5$. According to the calculations, the maximum value of the $\operatorname{Keff}_{i}$ efficiency criterion is achieved for the panel cell profile variant "h" in Figure 2 at the height values $H=80 \mathrm{~mm}, S=2.0 \mathrm{~mm}, S r=0.7 \mathrm{~mm}$.

Thermal studies of the optimal cellular panel in SolidWorks Simulation with sensing of the heat transfer surface allowed us to determine the average value of the specific heat flux $W_{A V G}=21.9 \mathrm{~W} / \mathrm{m}^{2}$, which corresponds to the value of the specific heat resistance $R=2.922\left(\mathrm{~m}^{2} \mathrm{~K}\right) / \mathrm{W}$. In the modern design of the passenger railway car body, thermal insulation is used with a thermal conductivity coefficient of $0.032 \mathrm{~W} /(\mathrm{m}$ $\mathrm{K})$ and a thickness of $80 \mathrm{~mm}$, the value of the specific thermal resistance is $2.5\left(\mathrm{~m}^{2} \mathrm{~K}\right) / \mathrm{W}$. Thus, the optimal model of the cellular panel profile has a $16.9 \%$ higher value of the specific thermal resistance than the base model. The weight of the body of the model passenger railway car, made of vacuum panels of optimal geometry, was $19767 \mathrm{~kg}$, which is less than the weight of the base model.

An experimental study of a vacuum panel with an optimal cellular profile was carried out according to the method (Balalaev et al., 2020a) on a prototype with overall dimensions of $160 \times 160$ and parameters $H=40$ $\mathrm{mm}, S=2.0 \mathrm{~mm}, S r=0.7 \mathrm{~mm}$. In the experiment, the value of the residual pressure in the internal cavities of the panel changed. The results of processing the experiments are shown in Figure 3.

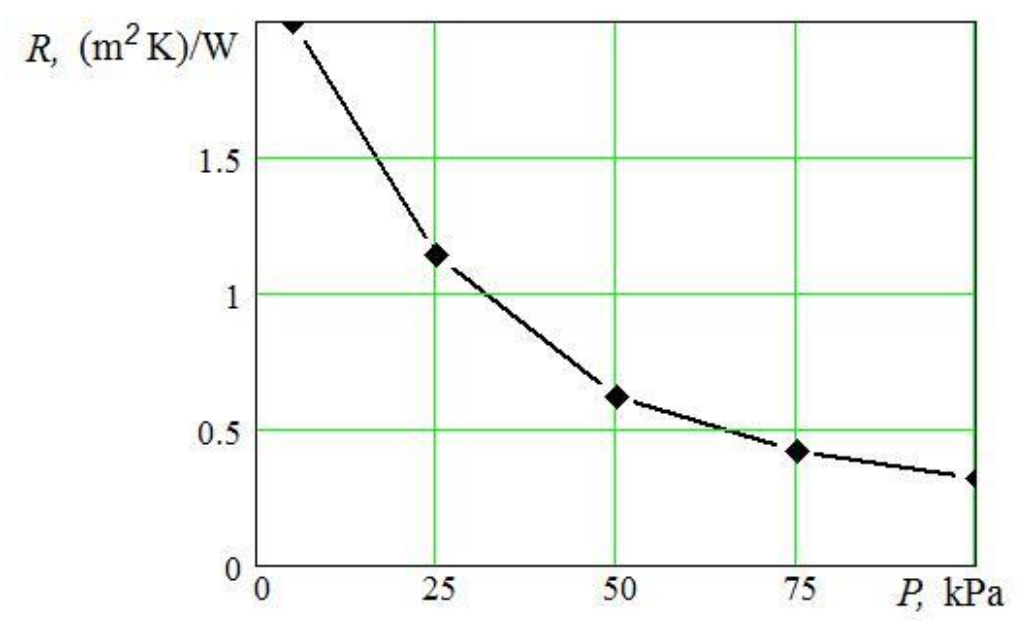

Figure 3. Dependence of the specific thermal resistance of the vacuum panel on the value of the residual pressure. 
As can be seen from the graph in Figure 3, at a residual pressure of $5 \mathrm{kPa}$, the specific thermal resistance of the vacuum panel is $2\left(\mathrm{~m}^{2} \mathrm{~K}\right) / \mathrm{W}$, which is less than the calculated value for the panel height $H=80 \mathrm{~mm}$ and the value for the base panel. However, the experiment was carried out on a vacuum panel with a height of $H=40 \mathrm{~mm}$, and its thermal resistance can be increased by adding layers of sound and thermal insulation in accordance with the recommendations (Balalaev et al., 2018b).

In the process of searching for the optimal geometry of the cellular structure panel, the best profile of a honeycomb panel with two rows of hexagonal cells was found from the maximum condition of the Keffi efficiency criterion at the values of height $H=80 \mathrm{~mm}$, wall thickness $S=2.0 \mathrm{~mm}$ and edge thickness $S r=$ $0.7 \mathrm{~mm}$. However, the choice of the values of the weight coefficients $\lambda_{1}$ and $\lambda_{2}$ was made arbitrarily, so further improvement of the method for finding the optimal geometry of the honeycomb panel will consist in establishing economically reasonable values of these coefficients.

The use of the optimal geometry of the honeycomb panel in the body structure of a passenger railway car as a vacuum thermal insulation allows for a $16.9 \%$ increase in the specific thermal resistance without increasing the body weight.

An experimental study of the optimal geometry of the vacuum panel allowed us to establish the dependence of the specific thermal resistance of the vacuum panel on the value of the residual pressure. According to the results obtained, the thermal resistance of the vacuum panel becomes higher than that of modern thermal insulation materials, if the residual pressure is less than $20 \mathrm{kPa}$.

\section{CONCLUSION}

In this paper, we propose a method for optimizing cellular profile vacuum panels by two parameters: mass and specific heat resistance. In accordance with this method, the geometry of the vacuum panel with two rows of hexagonal honeycombs was determined, which provides a significant increase in the specific thermal resistance of the walls of the passenger car body (by 16,9\%) and a slight decrease in the body weight for a given strength. This method will optimize the rail car body fencing, which reduces energy costs for heating the car in the winter. Experimental studies of the optimal cellular profile of the vacuum panel allowed us to establish the dependence of the specific thermal resistance of the vacuum panel on the value of the residual pressure.

\section{REFERENCES}

Andronchev, I. K. and Balalaev, A. N. (2013). Features of operation and repair of the carriage with a body from of aluminum panels, received by a method extrude. Vestnik Transporta Povolzhya, 3, 29-34.

Balalaev, A. N., Mokshanov A. S. and Popov D. A. (2015a). Production of vacuum heat-insulating article (Patent RU 2553629 (C1), F16L59/065). Federal Service for Intellectual Property of the Russian Federation. Retrieved March 30, 2021, from https://patenton.ru/patent/RU2553629C1

Balalaev, A. N., Mokshanov A. S. and Popov D. A. (2015b). Vacuum thermal insulation product (versions) (Patent RU 2571834 (C2), B60P3/20, B61D17/18, E04B1/80). Federal Service for Intellectual Property of the Russian Federation. Retrieved March 30, 2021, from https://patenton.ru/patent/RU2571834C2

Balalaev, A. N., Parenyuk, M. A., Arslanov, I. G. and Ziyatdinov, A. M. (2018a). Mass and heat-insulation properties of the bodies of passenger and insulated railway cars made of vacuum honeycomb panels. Journal of Applied Engineering Science, 16 (1), 50-59. 
Balalaev, A. N., Parenyuk, M. A., Sergeev, G. M. and Timkin, D. M. (2018b). Study of vacuum heatinsulation of the passenger car. Vestnik Transporta Povolzhya, 2, 13-20.

Balalaev, A. N., Parenyuk, M. A. and Timkin, D. M. (2020a). Method of measuring specific thermal resistance and device for implementation thereof (Patent RU2722088 (C1) G01N25/18). Federal Service for Intellectual Property of the Russian Federation. Retrieved March 30, 2021, from https://ru.espacenet.com/publicationDetails/biblio?DB=EPODOC\&II=0 \&ND=3\&adjacent=true $\&$ locale $=\mathrm{r}$ u_RU\&FT $=\mathrm{D} \&$ date $=20200526 \& \mathrm{CC}=\mathrm{RU} \& \mathrm{NR}=2722088 \mathrm{C} 1 \& \mathrm{KC}=\mathrm{C} 1$

Balalaev, A. N., Parenyuk, M. A. and Ziyatdinov, A. M. (2020b). Performance evaluation of vacuum thermal insulation for main oil and gas pipelines. International Journal of Advanced Science and Technology, 29 (7), 1843-1861.

European Cooperation for Space Standardization. (2008, July 31). ECSS-Q-ST-70-09C Measurements of thermo-optical properties of thermal control materials. Retrieved March 30, 2021, from https://ecss.nl/standard/ecss-q-st-70-09c-measurements-of-thermo-optical-properties-of-thermal-controlmaterials/

NASA. (1999). NASA/TP-1999-209263 Multilayer Insulation Material Guidelines MSFC-RPT-653A, MLI Design Guidelines. Retrieved March 30, 2021, from http://ayp0802.gotdns.ch/266.html

O'Hegarty, R., Reilly, A., West, R. and Kinnane, O. (2020). Thermal investigation of thin precast concrete sandwich panels. Journal of Building Engineering, 27, 100937.

Önder, A. and Robinson, M. (2020). Investigating the feasibility of a new testing method for GFRP/polymer foam sandwich composites used in railway passenger vehicles. Composite Structures 233, 111576.

Shavyrin, D. U., Krasnichenko, A. A. and Ivanov, N. L. (2017). Systems of air conditioning and heating of passenger cars: A course of lectures. Yekaterinburg, Russia: Ural State Transport University.

Yao, S., Xiao, X., Xu, P., Qu, Q. and Che, Q. (2018). The impact performance of honeycomb-filled structures under eccentric loading for subway vehicles. Thin-Walled Structures, 123, 360-370.

Zhuming, B. (2019). Finite element analysis applications: A systematic and practical approach. London, UK: Academic Press. 